Limnol. Rev. (2017) 17, 2: $61-70$

\title{
The ice regime of Lake Raduńskie Górne (Kashubian Lakeland, northern Poland)
}

\author{
Jacek Barańczuk $^{1^{*}}$, Elżbieta Bajkiewicz-Grabowska ${ }^{1}$, Katarzyna Barańczuk ${ }^{2}$, Wojciech Staszek ${ }^{3}$ \\ ${ }^{1}$ Department of Limnology, University of Gdansk, Bażyńskiego 4, 80-309 Gdańsk, Poland, e-mail: bgiojb@univ.gda.pl ( ${ }^{*}$ corresponding \\ author), e-mail: bajka37@wp.pl \\ ${ }^{2}$ Department of Economic Geography, University of Gdansk, Bażyńskiego 4, 80-309 Gdańsk, Poland \\ ${ }^{3}$ Department of Physical Geography and Environmental Protection, University of Gdańsk, Bażyńskiego 4, 80-309 Gdańsk, Poland, e-mail: \\ geosw@univ.gda.pl
}

\begin{abstract}
The paper presents assessment results of the ice dynamics on Lake Raduńskie Górne (Upper Radunia Lake) based on long-term observations of the course of ice phenomena. Interannual changes in lake ice phenology parameters (freeze-onset, ice-on, freeze duration, melt-onset, permanent ice cover duration, ice-off, melt duration) in the years 1961-2010 are discussed. In addition, the ice cover thickness was taken into consideration. The analysed parameters of ice phenology were compared to each other as well as to the mean air and water temperatures of the winter half-year (November-April). The main periods of the ice regime of the lake have been determined and described. The permanent ice cover constitutes on average $79 \%$, freeze-up period $13 \%$, and break-up period $8 \%$ of the whole time of ice phenomena. It was shown that the weather parameters crucial for ice formation are the mean air and surface water temperatures. On Lake Raduńskie Górne the ice phenomena can only occur when mean air temperature in the winter half-year, at Borucino wheather station, is lower than $4.9^{\circ} \mathrm{C}$, and water temperature (at a depth of $0.4 \mathrm{~m}$ ) is lower than $5.7^{\circ} \mathrm{C}$. In turn permanent ice cover is created when the mean air temperature of the winter half-year is lower than $3.9^{\circ} \mathrm{C}$. The maximum and mean ice cover thickness on Lake Raduńskie Górne ranged, respectively, from 0.5 to $50 \mathrm{~cm}$, and from 0.5 to $38.3 \mathrm{~cm}$. These parameters were strongly positively correlated $(\mathrm{r}=0.87-0.88, \mathrm{p}<0.05)$ with the duration of the ice cover period.
\end{abstract}

Key words: lake ice phenology, long-term ice cover changes, ice cover durability, ice thickness, trend analysis

\section{Introduction}

Variability is a feature of processes and phenomena that take place in the natural environment. This variability is determined by different kinds of factors resulting from both cyclical natural processes and increasing anthropopression. In order to properly interpret the course of parameters describing the variability of the environment, it is necessary to analyse data obtained for the longest possible period of time (Choiński et al. 2014). Lake Raduńskie Górne is the only one in the Kashubian Lakeland where ice phenomena have been systematically observed on a daily basis since 1961 .

Ice phenomena, a basic parameter describing lakes of the temperate zone, are one of the typical manifestations of annual variability of energetic conditions of lake system functioning (Lange 1993; Choiński 1995; Skowron 2011). They are closely linked to the thermal regime of a lake which determines their course (Barańczuk and
Marchlewicz 2003; Borowiak and Barańczuk 2004). Trends in ice regimes of lakes are mainly affected by the observed tendencies of climate change, particularly global warming manifesting itself with a decrease in the number of frost days (e.g., Hurrell 1995; Livingstone 1999; Filatov et al. 2003; Barańczuk and Borowiak 2005; Korhonen 2006). The frequent occurrence of days with positive air temperature during winter months since the 1980s as well as the shortening of thermal winters are other indicators of global climate changes (e.g., Assel 2004; Skowron 2011). Literature on lake ice phenomena of Polish lakes is very extensive (Chojnowski and Ciszewski 1964; Grześ 1974; Pasławski 1982; Barańczuk and Marchlewicz 2003; Skowron 2003; Girjatowicz 2003; Borowiak and Barańczuk 2004; Marszelewski and Skowron 2006; Choiński 2007; Maślanka and Barańczuk 2007; Skowron 2011; Choiński et al. 2013; Sobolewski et al. 2014; Choiński et al. 2014), although there is a lack of up-to-date data concerning lakes ob- 
served on a daily basis and the analysis of the particular parameters of ice phenology. Lake Raduńskie Górne is such a lake and the main objective of this study is to analyse ice phenomena during the period of 1961-2010 against the background of fluctuations in air and water temperature, as well as to answer the question of what the ice regime of this lake is and how its basic parameters change under the influence of air and water temperature.

\section{Study area}

In order to understand the details of lake ice phenology Lake Raduńskie Górne (54¹4'07" N, 1758'28" E) was selected. It is situated in the Polish Lowland, west of the Vistula River, in the Kashubian Lakeland mesoregion, in the catchement of the Upper Radunia River, being a tributary of the River Motława (Fig. 1).

It is a benchmark for the lakes of the East Pomeranian Lakeland (Kondracki 2011) having been systematically observed and studied by employees of the University of Gdańsk Limnological Station in Borucino, located on the northern bank of this lake. It is a ribbonstructural lake (Jańczak 2002) located at an altitude of $161.3 \mathrm{~m}$ above sea level. It is one of the largest lakes (387.2 ha) of the Radunia-Ostrzyce tunnel valley and the Kashubian Landscape Park (Maślanka 2007). The volume of the waters of the lake is $60158.7 \mathrm{dam}^{3}$. Lake Raduńskie Górne is a flow-through lake with a horizontal intensity of water exchange (flushing time) of 0.467 $\mathrm{yr}^{-1}$ and a water residence time of $2.14 \mathrm{yrs}$ (Borowiak 2000) which indicates that it is of a passive hydrological type (Pasławski 1975). A characteristic feature of

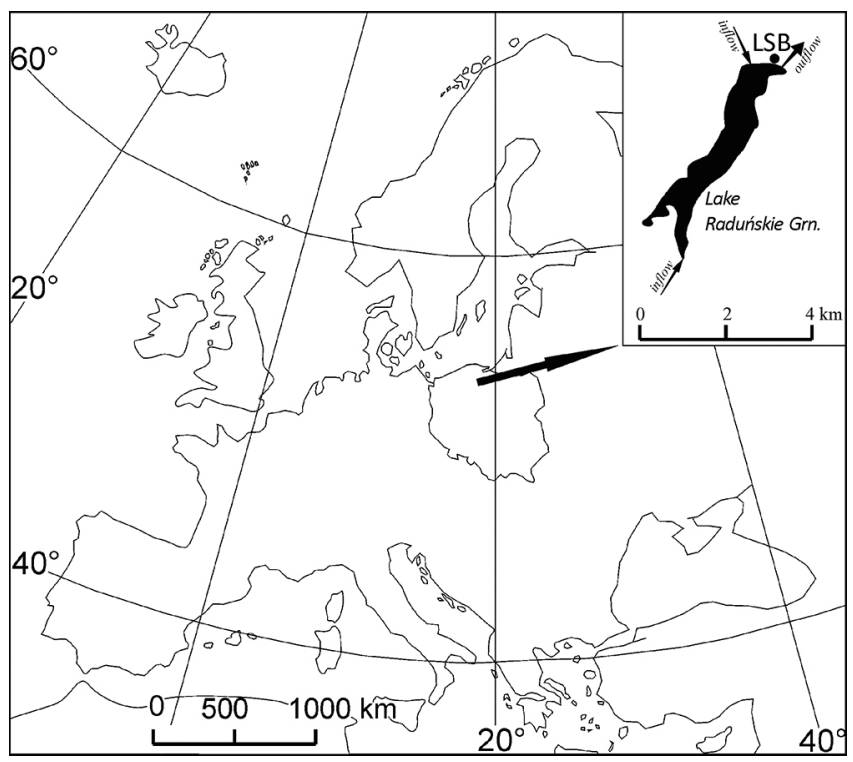

Fig. 1. Location map of the study area: LSB - Limnological Station in Borucino the lake is its distinctive structure of water balance with domination of underground inflow constituting more than $50 \%$ of the total water inflow (Borowiak and Barańczuk 2004).

\section{Methods}

Initial material for the analysis which contains data on air temperature and ice phenomena was obtained at the University of Gdańsk Limnological Station in Borucino located in the north-western basin (Borucino Basin) of Lake Raduńskie Górne. This material covers the period of 1961-2010 and the data concern everyday observation of ice phenomena which began and has been measured continuously since the establishment of the research station. The measurements of ice phenomena on Lake Raduńskie Górne are performed by an employee of the Limnological Station in accordance with the IMGW (Institute of Meteorology and Water Management) recommendations near a water gauging post (Swirski 1947), in a daily cycle. The measurement data provided by the Limnological Station in Borucino used for the purposes of this study contained information on the daily air and water temperatures and the following ice phenomena: frazil ice, bank ice, partial ice cover, total ice cover and ice floe.

\section{Results}

During the period of 1961-2010, more or less intensive, ice phenomena were observed on Lake Raduńskie Górne each winter. Their course indicated significant inter-annual fluctuations (Fig. 2) involving large fluctuations in dates of appearance and disappearance of the ice cover as well as in duration of its various forms. Usually, the first form of ice appears on the lake in the last decade of December, on the $31^{\text {st }}$ of this month (the median value is the $28^{\text {th }}$ of December), but not earlier than in the third decade of November $\left(26^{\text {th }}\right.$ day $)$, which took place in the hydrological year of 1999 , and not later than on the $25^{\text {th }}$ February (the hydrological year of 2007) (Fig. 2). Therefore, the difference between the initial dates on which the presence of any form of ice is observed (freeze-onset date) is 92 days. In the analysed period the beginning of the ice phenomena was observed most often on the following days: $1^{\text {st }}$ December $(1974,1989,1994), 14^{\text {th }}$ December $(1964,1984,2002)$ and $18^{\text {th }}$ January $(1961,1978,1988)$.

The time of disappearance of the ice phenomena is also varied (Fig. 2). They can be observed until the period of the $8^{\text {th }}$ January (1990) $-25^{\text {th }}$ April (1970) thus, the difference between the extreme dates of ice-off equals 108 days. The average date when Lake Raduńskie Górne becomes totally ice-free is $29^{\text {th }}$ March, although during 

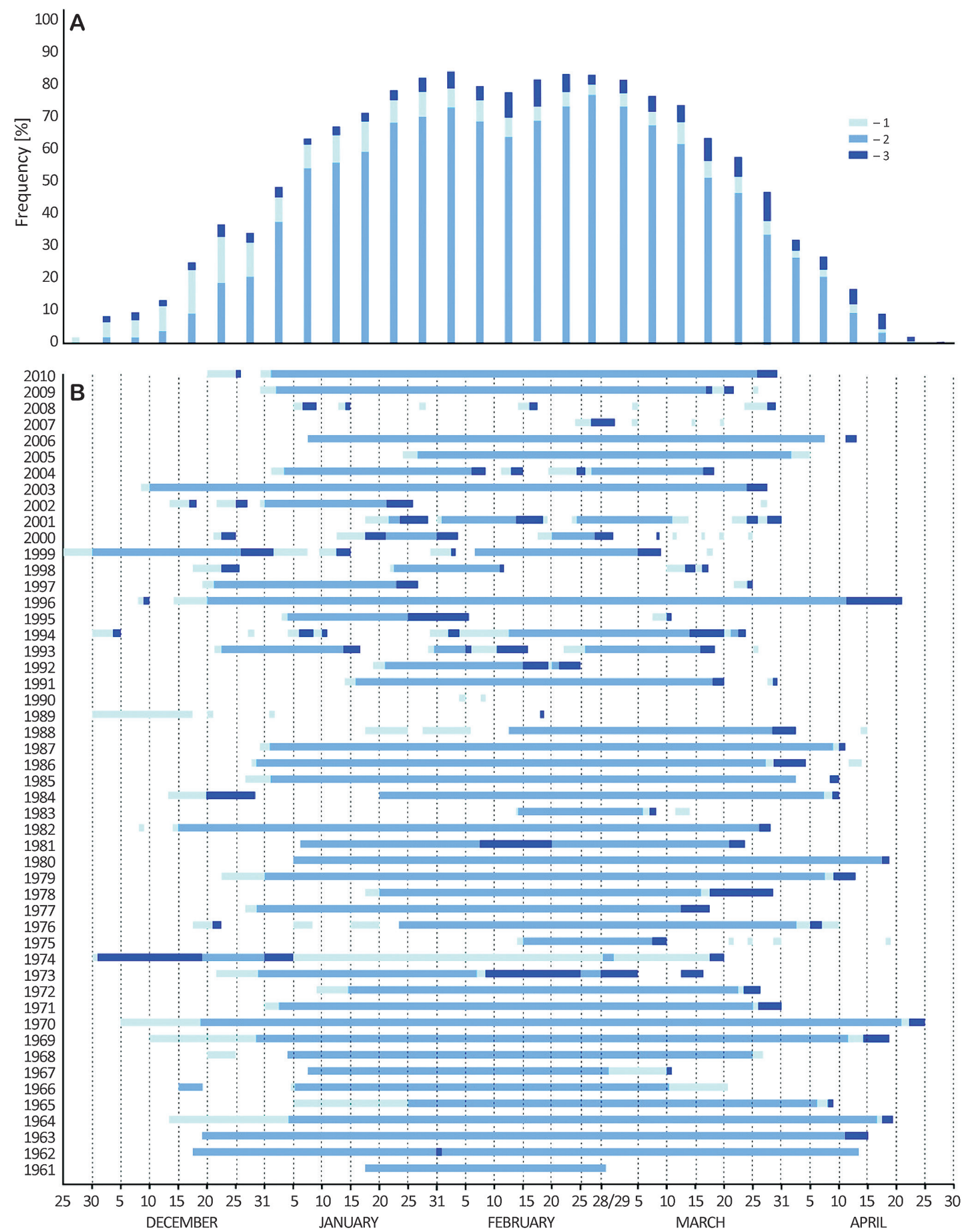

Fig. 2. Diagrams showing mean pentad frequencies (\%) of the number of days with frazil ice, bank ice, partial ice cover, permanent ice cover and ice floe (A), and the course of ice phenomena on Lake Raduńskie Górne (B) in the period of 1961-2010. Data provided by the Limnological Station in Borucino. Explanation: 1 - freeze-up period (frazil ice, bank ice and partial ice cover), 2 - permanent ice cover, 3 - break-up period (ice floe) 
Table 1. Duration of the ice season, the ice phenomena and various forms of ice on Lake Raduńskie Górne in the period of 1961-2010 (data provided by the Limnological Station in Borucino)

\begin{tabular}{|c|c|c|c|c|c|c|c|}
\hline \multirow{2}{*}{ Winter season } & \multicolumn{5}{|c|}{ Duration [in days] } & \multicolumn{2}{|c|}{ Ice season } \\
\hline & Ice season $^{1}$ & Ice phenomena ${ }^{2}$ & Freeze-up period & Ice cover & Break-up period & beginning & end \\
\hline 1961 & 42 & 42 & - & 42 & - & 18.01 & 28.02 \\
\hline 1962 & 118 & 118 & - & 117 & 1 & 17.12 & 13.04 \\
\hline 1963 & 117 & 117 & - & 113 & 4 & 20.12 & 15.04 \\
\hline 1964 & 128 & 128 & 23 & 103 & 2 & 14.12 & 19.04 \\
\hline 1965 & 89 & 89 & 17 & 71 & 1 & 11.01 & 09.04 \\
\hline 1966 & 96 & 80 & 12 & 68 & - & 16.01 & 21.03 \\
\hline 1967 & 58 & 58 & 5 & 52 & 1 & 08.01 & 06.03 \\
\hline 1968 & 98 & 89 & 7 & 82 & - & 21.12 & 27.03 \\
\hline 1969 & 129 & 129 & 21 & 104 & 4 & 11.12 & 18.04 \\
\hline 1970 & 141 & 141 & 15 & 123 & 3 & 06.12 & 25.04 \\
\hline 1971 & 90 & 90 & 4 & 81 & 5 & 01.01 & 31.03 \\
\hline 1972 & 78 & 78 & 6 & 68 & 4 & 10.01 & 27.03 \\
\hline 1973 & 85 & 78 & 10 & 42 & 26 & 22.12 & 16.03 \\
\hline 1974 & 110 & 110 & 72 & 14 & 24 & 01.12 & 20.03 \\
\hline 1975 & 64 & 29 & 9 & 20 & - & 15.02 & 19.04 \\
\hline 1976 & 115 & 93 & 19 & 71 & 3 & 18.12 & 10.04 \\
\hline 1977 & 108 & 83 & 9 & 74 & - & 27.12 & 13.04 \\
\hline 1978 & 71 & 71 & 4 & 55 & 12 & 18.01 & 29.03 \\
\hline 1979 & 112 & 112 & 10 & 98 & 4 & 23.12 & 13.04 \\
\hline 1980 & 106 & 106 & - & 104 & 2 & 05.01 & 19.04 \\
\hline 1981 & 108 & 82 & - & 64 & 18 & 07.12 & 24.03 \\
\hline 1982 & 110 & 105 & 2 & 101 & 2 & 09.12 & 28.03 \\
\hline 1983 & 29 & 26 & 5 & 20 & 1 & 14.02 & 14.03 \\
\hline 1984 & 119 & 97 & 8 & 80 & 9 & 14.12 & 10.04 \\
\hline 1985 & 99 & 99 & 6 & 91 & 2 & 27.12 & 04.04 \\
\hline 1986 & 108 & 101 & 4 & 90 & 7 & 28.12 & 14.04 \\
\hline 1987 & 102 & 102 & 3 & 98 & 1 & 31.12 & 11.04 \\
\hline 1988 & 89 & 70 & 19 & 44 & 7 & 18.01 & 15.04 \\
\hline 1989 & 80 & 21 & 20 & 1 & - & 01.12 & 18.02 \\
\hline 1990 & 4 & 2 & 1 & - & 1 & 05.01 & 08.01 \\
\hline 1991 & 75 & 67 & 3 & 61 & 3 & 15.01 & 30.03 \\
\hline 1992 & 37 & 37 & 3 & 27 & 7 & 20.01 & 25.02 \\
\hline 1993 & 95 & 72 & 13 & 47 & 12 & 22.12 & 26.03 \\
\hline 1994 & 114 & 67 & 23 & 31 & 13 & 01.12 & 24.03 \\
\hline 1995 & 66 & 38 & 4 & 21 & 13 & 04.01 & 11.03 \\
\hline 1996 & 135 & 131 & 17 & 113 & 1 & 09.12 & 21.04 \\
\hline 1997 & 96 & 73 & 4 & 64 & 5 & 20.12 & 25.03 \\
\hline 1998 & 90 & 37 & 11 & 19 & 7 & 18.12 & 17.03 \\
\hline 1999 & 113 & 87 & 17 & 52 & 18 & 26.11 & 18.03 \\
\hline 2000 & 95 & 43 & 13 & 16 & 14 & 22.12 & 25.03 \\
\hline 2001 & 71 & 57 & 15 & 30 & 12 & 19.01 & 30.03 \\
\hline 2002 & 104 & 38 & 9 & 22 & 7 & 14.12 & 27.03 \\
\hline 2003 & 110 & 110 & 2 & 104 & 4 & 09.12 & 28.03 \\
\hline 2004 & 77 & 70 & 10 & 52 & 8 & 02.01 & 18.03 \\
\hline 2005 & 71 & 71 & 7 & 64 & - & 25.01 & 05.04 \\
\hline 2006 & 96 & 93 & - & 91 & 2 & 08.01 & 13.04 \\
\hline 2007 & 24 & 8 & 6 & - & 2 & 25.02 & 20.03 \\
\hline 2008 & 84 & 17 & 12 & - & 5 & 06.01 & 29.03 \\
\hline 2009 & 86 & 83 & 6 & 74 & 3 & 31.12 & 26.03 \\
\hline 2010 & 101 & 96 & 7 & 84 & 5 & 21.12 & 30.03 \\
\hline Mean & 91 & 77 & 10 & 61 & 6 & 31.12 & 29.03 \\
\hline
\end{tabular}

${ }^{1}$ Ice season: number of days between the earliest freeze-onset and the latest ice-off dates. Ice season includes days without ice if they occurred between these two dates; ${ }^{2}$ Ice phenomena: number of days on which any form of ice was observed. 
the period of 1960-2010 the total ice cover generally disappeared on the $13^{\text {th }}$ April.

Taking under consideration the extreme dates of freeze-onset (26.11.1999; Table 1) and ice-off (25.04.1970; Table 1), the hypothetical duration of the ice season is 151 days. During the analysed 50-year period there was no single observation of a such long period of ice season occurrence. The longest one was recorded in 1970 and it lasted 141 days, and the shortest one took place in 1990 and lasted only 4 days. The average ice season on Lake Raduńskie Górne lasts 91 days, although an ice season lasting three months (96 days) was most frequently observed on this lake (Table 1).

In an average year the ice phenomena on Lake Raduńskie Górne were observed for 77 days (standard deviation STD $=34$ days constitutes $44 \%$ of the arithmetic mean). Again 1970 was the year during which the total duration of occurrence of various forms of ice were observed for the longest time of 141 days, thus the ice phenomena occurred for the whole ice season. In 1990 they were observed for only 2 days (Table 1). During the winter seasons of 1961-2010 they were usually observed on the lake for 71-90 days.

The course of the ice phenomena on the lake is not of a continuous nature every winter. There were 15 winters with one break (ice-free water surface phase) during the course of the ice phenomena thus, with two ice phases (an ice phase is a portion of a time of uninterrupted occurrence of ice phenomena expressed in days), three winters with three ice phases, seven winters with four ice phases, and one winter with five (1999), six (2008) and eight (2000) ice phases (Fig. 2). Taking into account the whole analysed period of the ice phenomena observations, it can be generally stated that the frequency of their occurrence, and therefore the probability of their appearance, on Lake Raduńskie Górne gradually increases from the last pentad of November to the first pentad of February, then decreases from the first to the third pentad of February, increases once again from the third to the fifth pentad of this month and then decreases from the end of February to the fifth pentad of April, when the ice phenomena ultimately ends (Fig. 2).

The years 1990, 2007 and 2008 were particularly interesting in the scope of the ice phenomena on Lake Raduńskie Górne (Fig. 2). In the winter of 1990 only two days with ice phenomena were observed (mean air temperature during winter half-year was $3.6^{\circ} \mathrm{C}$, sum of the negative air temperatures was $-75.7^{\circ} \mathrm{C}$, and mean water temperature of the winter half-year was $4.9^{\circ} \mathrm{C}$ ). In 2007 the ice phenomena on the lake were observed for eight days with three phases of ice-free water surface (mean air temperature was $4.2^{\circ} \mathrm{C}$, sum of the negative air temperatures was $-74.2^{\circ} \mathrm{C}$, and mean water temperature was $5.5^{\circ} \mathrm{C}$ ) while in the winter of 2008 they

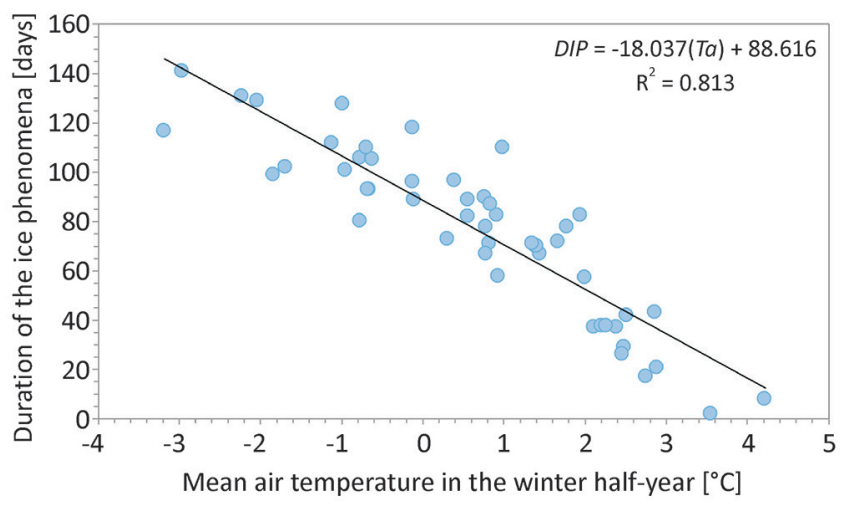

Fig. 3. Relationship between duration of the ice phenomena (DIP) on Lake Raduńskie Górne and the mean air temperature (Ta) in the winter half-year (November-April) at Borucino Station in the period of 1961-2010

were observed for 17 days with five phases of ice-free water surface (Table 1). During the winter season of 2008 mean air temperature was $2.8^{\circ} \mathrm{C}$, sum of negative air temperatures was $-83.1^{\circ} \mathrm{C}$, and mean water temperature was $4.4^{\circ} \mathrm{C}$.

The number of days with ice phenomena $(D I P)$ on Lake Raduńskie Górne is strongly correlated with the value of mean air temperature of the winter half-year (November-April) at Borucino weather station (Fig. $3)$. The linear regression between these two variables is as follows: $D I P=-18.037(\mathrm{Ta})+88.616, \mathrm{R}^{2}=0.813, \mathrm{p}=$ 0.05 , where: $\mathrm{Ta}$ - mean air temperature of the winter half-year at Borucino (in Celsius degrees, ${ }^{\circ} \mathrm{C}$ ), DIP duration of ice phenomena (in days). This relationship indicates that the ice phenomena on Lake Raduńskie Górne occur when the mean air temperature of the winter half-year (November-April) at Borucino is lower than $4.9^{\circ} \mathrm{C}$.

A slightly weaker correlation was found between the number of days with the ice phenomena $(D I P)$ and

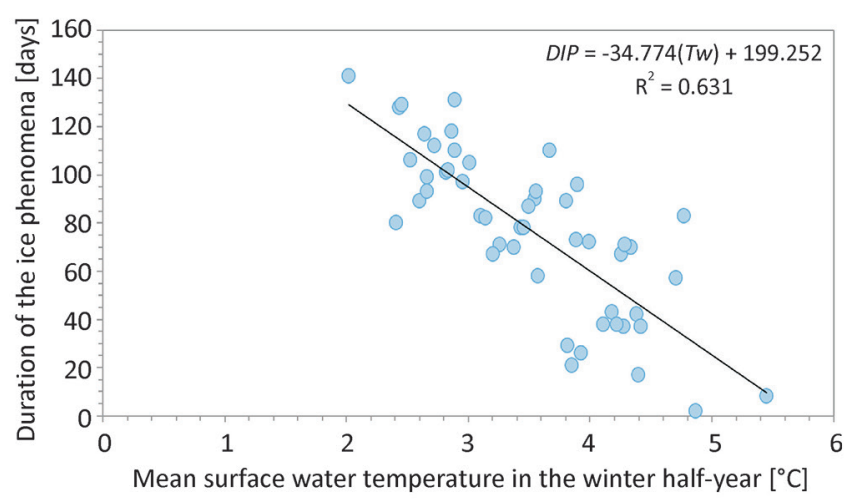

Fig. 4. Relationship between duration of the ice phenomena (DIP) on Lake Raduńskie Górne and the mean surface water temperature (Tw) in the winter half-year (November-April) in the period of 1961-2010 
the mean surface water temperature (at the depth of $0.4 \mathrm{~m}$ ) during the winter half-year ( $T w$, in Celsius degrees) (Fig. 4). In turn this relationship describes the linear regression equation in form: $D I P=-34.774(\mathrm{Tw})$ $+199.252, \mathrm{R}^{2}=0.631, \mathrm{p}=0.05$. This relationship predicts that the ice phenomena on Lake Raduńskie Górne can occur when the mean water temperature during the winter half-year is lower than $5.7^{\circ} \mathrm{C}$.

The measurement data show that in the period of 1961-2010 on the day of freeze onset the temperature of the surface water in Lake Raduńskie Górne ranged between $3.3^{\circ} \mathrm{C}(2009)$ and $0.3^{\circ} \mathrm{C}(1966), 1.8^{\circ} \mathrm{C}$ on average and most frequently $-2.3^{\circ} \mathrm{C}$. On the day on which the lake is totally ice-free (ice-off date) the temperature of the surface water ranged between $1.3^{\circ} \mathrm{C}(1990)$ and $8.4^{\circ} \mathrm{C}$ (1996), $3.9^{\circ} \mathrm{C}$ on average, and most frequently $-2.0^{\circ} \mathrm{C}$.

The most frequent first sign of the onset of the ice season on Lake Raduńskie Górne is the emergence of bank ice or partial ice cover, a less frequent sign is frazil ice (Fig. 2). Only in the years of 1961, 1962, 1963, 1980, 1981 and 2006 were the above-mentioned ice forms not observed on the lake before the creation of the permanent ice cover (Fig. 2, Table 1). In those years the entire surface of the lake was immediately covered by a thin layer of primary ice.

During the considered period, mean duration time of these forms of ice on Lake Raduńskie Górne was 10 days, while the median was eight days. The longest duration of freeze-up period was recorded in 1974 when it lasted through 72 days. In 1964, 1969, 1989 and 1994 the freeze-up phases ranged between 20 and 23 days, which is considered a relatively long period. However, the most frequent duration of this phase during the whole analysed period was only four days. On average, freeze-up periods constituted $13 \%$ of the time of all ice phenomena on Lake Raduńskie Górne. In some years there were winters when bank ice, partial ice cover or frazil ice were the only forms of ice occurring on the lake. In the winter of 1974 these forms of ice were present for $65 \%$ of the time when ice phenomena were observed, in 1989 for 95\%, in 1990 for 50\%, in 2007 for $75 \%$ and in 2008 for $71 \%$.

There were also winters when bank ice and partial ice cover were observed several times during the ice season (Fig. 2). Separated freeze-up periods were recorded seven times in the winters of 1994, 2000 and 2001, six times in the winter of 2008 and five times in 1975, 1976, 1993 and 1999. Nonetheless, they were most frequently (21 winter seasons) observed twice a season. The average number of breaks in partial ice cover, when the water surface becomes ice-free, is one during the whole analysed period.

Emergence of permanent ice cover on Lake Raduńskie Górne is usually preceded by bank ice for- mation with the exception of the years of 1961-1963, 1966, 1967 and 2006 when the ice cover set the beginning of the ice phenomena on this lake (same freezeonset and ice-on dates) as well as the years of 1990, 2007 and 2008 when there was no permanent ice cover at all (Fig. 2, Table 1). According to observation data the earliest date of ice-on was $1^{\text {st }}$ December 1999, while the latest, $18^{\text {th }}$ February 1989. Permanent ice cover most frequently appears on $20^{\text {th }}$ December. The median value of its appearance is $4^{\text {th }}$ January and during an average winter of the analysed period it covers the lake on $8^{\text {th }}$ January. The period between $22^{\text {nd }}$ January (2002) and $21^{\text {st }}$ April (1970) (Fig. 2) is the one which sets the end of the permanent ice cover on Lake Raduńskie Górne. On average it is $18^{\text {th }}$ March, and most frequently $-28^{\text {th }}$ February. The median ice-off date is $23^{\text {rd }}$ March.

The duration of permanent ice cover on the investigated lake ranged from one day in 1989 to 123 days in 1970, and 65 days a year on average (Table 1). Permanent ice cover was present on the lake for more than 100 days in the following years: 1962-1964, 1969, 1980, 1982, 1996 and 2003 (Fig. 2, Table 1). The most frequentlly observed duration was 52 days. For half of the analysed period permanent ice cover was present for 68 days.

If the permanent ice cover has already formed it remains until the end of the ice season, which usually ends with a short (in average 7 days) period of ice floe. In the years 1962, 1966, 1973, 1974, 1981, 1992, 1994, 1999, 2000, and 2004 permanent ice cover was formed twice during the ice season, and in 1993 and 2004 even three times (Fig. 2). The length of a break between the subsequent periods of permanent ice cover ranged from one day (1962) to 58 days (1974). Permanent ice cover was the main form of ice phenomena observed on lake (Fig. 2). Its relative share in all ice phenomena ranges from zero to $100 \%, 79 \%$ on average. The relationship between the permanent ice cover duration $(P I C)$ and the duration of ice phenomena $(D I P)$ observed on Lake Raduńskie Górne can be described in the following way: $P I C=0.945(D I P)-11.394, \mathrm{R}^{2}=0.827, \mathrm{p}=0.05$.

The thickness of the ice cover during the ice season on Lake Raduńskie Górne is strongly correlated with the time of its occurrence. The relationship between maximum ice thickness (MIT) and the duration of the permanent ice cover period $(P I C)$ is described by the following equation: $M I T=0.357(P I C), \mathrm{R}^{2}=0.769, \mathrm{p}=$ 0.05 ; as well as between average thickness of the ice cover $(A I T)$ and the time of permanent ice cover occurrence $(P I C)$ by the following one: $A I T=0.251(P I C), \mathrm{R}^{2}$ $=0.764, \mathrm{p}=0.05$.

During the period of 1961-2010, the thickness of the ice cover measured on the first day of its appearance ranged from 0.5 to $6.0 \mathrm{~cm}, 2.0 \mathrm{~cm}$ on average, most frequently $-1.0 \mathrm{~cm}$. The ice was thickening for three 


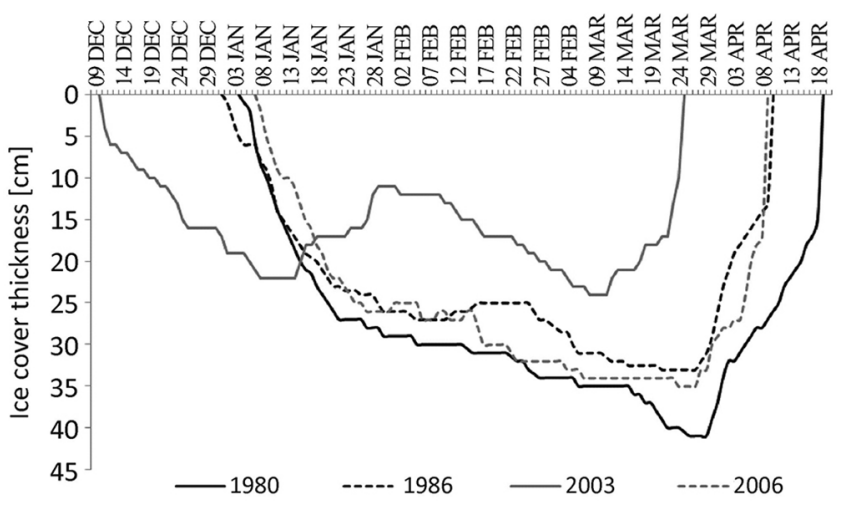

Fig. 5. Time changes of the ice cover on Lake Raduńskie Górne in selected years

months on average and it reached its maximum thickness in the last decade of March. The phase of the ice cover thickness decrease was almost three times shorter than the phase of its thickening (Fig. 5). On the last day of the permanent ice cover occurrence the ice thickness ranged from 0.4 to $31 \mathrm{~cm}, 11 \mathrm{~cm}$ on average, most frequently $-10 \mathrm{~cm}$.

Maximum thickness of the permanent ice cover ranged from $0.5 \mathrm{~cm}$ (1989) to $50 \mathrm{~cm}$ (1970) and it was most frequently $19 \mathrm{~cm}$ (Fig. 6), while the mean thickness ranged from $0.5 \mathrm{~cm}$ (1989) to $38.3 \mathrm{~cm}$ (1970) and it was most frequently $11.5 \mathrm{~cm}$ (Fig. 6). During an average winter of the analysed period, the ice cover on Lake Raduńskie Górne had a mean thickness of $17 \mathrm{~cm}$ and a maximum thickness of $24 \mathrm{~cm}$. The relationship between the average (AIT) and the maximum ice thickness $(M I T)$ is described by the following quotation: $M I T=1.401(A I T), \mathrm{R}^{2}=0.952, \mathrm{p}=0.05$.

A statistically significant relationship between the duration of the permanent ice cover and the mean air temperature of the winter half-year (November-April) was found (Fig. 7). The permanent ice cover does not form when the air temperature in the winter half-year reaches a mean value higher than $3.9^{\circ} \mathrm{C}$.

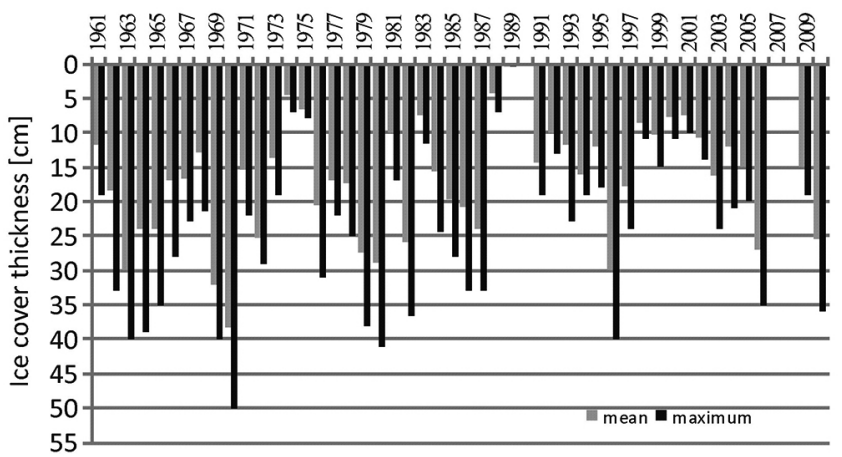

Fig. 6. Mean and maximum thickness of the ice cover on Lake Raduńskie Górne during the winter seasons in the period of 19612010

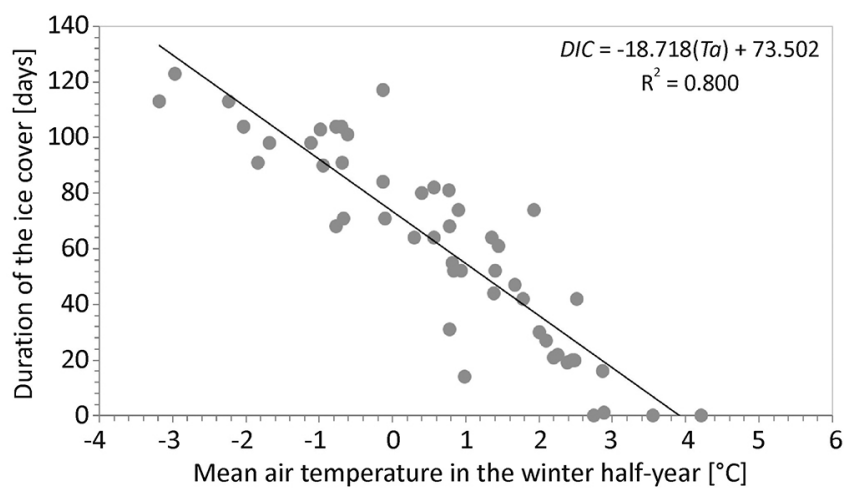

Fig. 7. Relationship between the number of days with the permanent ice cover on Lake Raduńskie Górne and the mean air temperature in the winter half-year (November-April) at Borucino in the period of 1961-2010

Ice floe is usually the last observed form of the ice on Lake Raduńskie Górne. During the analysed period it was not observed on the lake in 1961, 1966, 1968, 1975, 1977, 1989 and 2005 (Table 1) while in 1962, 1965, 1967, 1983, 1987, 1990 and 1996 it was present for only one day. During an average winter the ice floe constituted $8 \%$ of all ice phenomena occurring on the lake. In 1990 it constituted 50\%, and in 1973, 1995, 2000 and 2008 approximately $30 \%$ (Table 1 ). The ice floe appeared not earlier than in the first pentade of December (02.12.1974) and not later than in the fifth pentade of April (22.04.1970). On average, it appears on the lake in the fourth pentade of February (on $19^{\text {th }}$ day). It appeared most frequently on $13^{\text {th }}$ April.

Ice-off date indicated the end of the ice phenomena occurrence. The ice floe totally melts in the sixth pentad of April (25.04.1970) at the latest. However, it usually takes place during the sixth pentad of March ( $27^{\text {th }}$ day). The average date of ice-off is set by the fifth pentad of March ( $21^{\text {st }}$ day). The longest duration of the ice floe, which was 26 days, was observed in 1973 (Table 1). Its average duration was seven days, and the median value was five days.

\section{Discussion}

Studies on the occurrence and changes in thickness of ice cover are considered basic research and they have been undertaken by a growing group of limnologists recently (e.g., Assel 1999; Livingstone 1999; Kärkäs 2000; Hodgkins et al. 2002; Marszelewski and Skowron 2006; Skowron 2011). This is because lakes are perceived as a vital element of the natural environment which affects them (Williams at al. 2004).

The appearance and disappearance of ice phenomena on Polish lakes show some degree of regularity on both an annual and multiannual scale (Grześ 1974; 
Górniak and Pękala 2001; Borowiak and Barańczuk 2004; Skowron 2011; Choiński et al. 2014). Some extreme situations are also observed, for example, when a lake does not freeze at all or when ice phenomena appear only for a short period of time or last too long. Such situations are indicated using dates of the earliest and the latest appearance of ice phenomena on lakes (Borowiak and Barańczuk 2004; Barańczuk and Borowiak 2005; Marszelewski and Skowron 2006, Marszelewski and Skowron 2009). According to the above-mentioned authors, duration of ice phenomena on lakes differs substantially. When compared to others, Lake Raduńskie Górne does not diverge significantly from the other lakes in Poland. The shortest duration of ice phenomena in Poland varies from zero (lakes: Charzykowskie and Lubie), through four (Lake Raduńskie Górne), to 48 days (Lake Studzieniczne), while the longest duration of ice phenomena varies from 118 (Lake Lubie), through 141 (Lake Raduńskie Górne) to 151 days on Lake Jeziorak (Borowiak and Barańczuk 2004; Barańczuk and Borowiak 2005; Marszelewski and Skowron 2006; Marszelewski and Skowron 2009).

Similar tendencies are observed in the case of permanent ice cover occurrence. Although its occurrence on Polish lakes is something normal, there are winters with no permanent ice cover (Marszelewski and Skowron 2009; Borowiak and Barańczuk 2004). Lack of ice cover was more often observed on lakes situated in the western part of North Poland, specifically, lakes situated west of the Vistula River (Gopło, Lubie, Sławskie and Osiek) (Marszelewski and Skowron 2009). As for Lake Raduńskie Górne, during the research period there were only three cases when there was no permanent ice cover (Table 1). In the eastern part of Poland there was only one winter season with no ice cover (1975) on Lake Hańcza (Marszelewski and Skowron 2009), while on Lake Wigry it was present every year (Dąbrowski 2008). A similar situation is observed in the cases of lakes situated in southern Poland, especially in the Tatra Mountains where ice cover was present on Lake Czarny Staw (Choiński 2016). Some warmer periods may be observed during winters which modify the "model" course of ice phenomena on lakes of the temperate climatic zone (Barańczuk and Marchlewicz 2003).

Changes in dates specifying the beginning and end of particular phases of ice phenomena development are also observed (Kärkäs 2000; Korhonen 2006). Curently, ice phenomena appear and disappear earlier. Moreover, the duration of permanent ice cover is also shorter when compared to the duration of all ice phenomena. In this context, when compared to others, Lake Raduńskie Górne does not diverge significantly from the other lakes in Poland (Borowiak and Barańczuk 2004).
The course of ice phenomena on lakes depends on many factors. The most important are climatic conditions, especially air temperature and wind speed (Livingstone 1999; Hodgkins et al. 2002; Williams et al. 2004; Assel 2004). Systematic observations conducted over still extending periods show noticeable changes in the course and basic features of ice phenomena which are the results of global climate change, clearly visible in the northern hemisphere (Assel 1999; Filatov et al. 2003; Naumenko et al. 2008; Trusewicz et al. 2009; Skowron 2011; Choiński et al. 2014).

\section{Conclusions}

On the basis of the analysis performed and the comparison of the available data resulting from the research objective, significant information on the ice regime of Lake Raduńskie Górne was obtained. The study has shown that:

1. Permanent ice cover is the main form of the ice regime of Lake Raduńskie Górne. In the winters of the analysed period of 1961-2010 permanent ice cover constituted on average $79 \%$ of all ice phenomena observed on Lake Raduńskie Górne, being a benchmark for the whole region. The various forms of ice during the freeze-up period (bank ice, partial ice cover and frazil ice) constituted $13 \%$ of the ice phenomena while the ice floe $-8 \%$ of all ice phenomena observed on the lake.

2. The ice phenomena form on Lake Raduńskie Górne when the mean air temperature of the winter halfyear (November-April) at Borucino weather station is lower than $4.9^{\circ} \mathrm{C}$, yet the permanent ice cover forms when the mean air temperature is not higher than $3.9^{\circ} \mathrm{C}$.

3. The ice cover thickens for three months on average, reaching its maximum thickness at the end of March. The average thickness of the ice cover on Lake Raduńskie Górne is $17 \mathrm{~cm}$, while the maximum thickness is $24 \mathrm{~cm}$. The phase of ice cover thickening is almost three times longer than the phase of its melting.

4. The ice cover thickness, the length of the ice season and the ice cover durability are mainly affected by the total sum of average daily values of negative air temperature.

5. The highest frequency of occurrence of the ice phenomena is observed in the first pentad of February.

\section{References}

Assel R., 1999, Great Lakes ice cover, [in:] Lam D.C.L., Schertzer W.M. (eds.) Polential climate change effects on 
Great Lakes hydrodynamics and water quality, American Society of Civil Engineers (ASCE) Press, Reston: 6.1-6.21.

Assel R., 2004, Lake Erie ice cover climatology - Basin averaged ice cover: winters 1898-2002. NOAA Technical Memorandum GLERL-128, NOAA Great Lakes Environmental Research Laboratory, Ann Arbor, 15 pp.

Barańczuk J., Marchlewicz R., 2003, Diversity of development of ice phenomena in chosen lakes of Kaszubskie Lakeland in winter 2003, Limnol. Rev. 3: 25-30.

Barańczuk J., Borowiak D., 2005, Zjawiska lodowe jezior (Lakes ice cover), [in:] Lange W. (ed.), Jeziora górnej Raduni i jej zlewnia w badaniach $\mathrm{z}$ udziałem Stacji Limnologicznej w Borucinie (Lakes of the upper Radunia River and its catchment in research with the participation of the Limnological Station in Borucino), Ser. Bad. Limnol. 3, Wydaw. KLUG, Gdańsk: 251-260 (in Polish, English summary).

Borowiak D., 2000, Reżimy wodne i funkcje hydrologiczne jezior Niżu Polskiego (Water regimes and hydrological functions of Polish Lowland lakes), Ser. Bad. Limnol. 2, Wydaw. KLUG, Gdańsk, 164 pp (in Polish, English summary).

Borowiak D., Barańczuk J., 2004, Secular fluctuations of ice phenomena in Raduńskie Górne Lake, Kashubian Lakeland, Limnol. Rev. 4: 17-24.

Choiński A., 1995, Zarys limnologii fizycznej Polski (An outline of physical limnology of Poland), Wydaw. Nauk. UAM, Poznań, 298 pp (in Polish).

Choiński A., 2007, Examples of variation in ice cover thickness in mountain and lowland lakes in Poland, Limnol. Rev. 7(1): 11-18.

Choiński A., 2016, Ice phenomena on Lake Czarny Staw pod Rysami, Limnol. Rev. 16(3): 165-169.

Choiński A., Ptak M., Skowron M., 2014, Tendencje zmian zjawisk lodowych jezior Polski w latach 1951-2010 (Tendencies of changes of the ice phenomena in Polish lakes in the period 1951-2010), Prz. Geogr. 86(1): 23-40 (in Polish, English summary).

Choiński A., Ptak M., Strzelczak A., 2013, Areal variation in ice cover thickness on Lake Morskie Oko (Tatra Mountains), Carpat. J. Earth Environ. Sci. 8(3): 97-102.

Chojnowski S., Ciszewski R., 1964, Z badań nad pokrywą lodową Jeziora Mikołajskiego (Investigaions of the ice cover of Lake Mikolajskie), Biul. PIHM 8: 1-39 (in Polish).

Dąbrowski M., 2008, Zjawiska lodowe na jeziorze Wigry (Ice phenomena on the Wigry Lake), Pr. Kom. Paleogeogr. Czwartorz. PAU 6: 125-133 (in Polish, English summary).

Filatov N., Nazarova L., Salo Y., 2003, Climate changes and water resources in the region of the largest European Lakes, [in:] Simola H. (ed.), Proc. of the Fourth International Lake Ladoga Symposium 2002, University of Joensuu, Joensuu: 31-36.
Girjatowicz J.P., 2003, The influence of the North Atlantic Oscillation on ice conditions in coastal lakes of the Southern Baltic Sea, Ann. Limnol. - Int. J. Lim. 39(1): 71-80.

Górniak A., Pękala M., 2011, Zjawiska lodowe jezior północno-wschodniej Polski (Ice phenomena on lakes of north-eastern Poland), Prz. Geofiz. 46 (1-2): 91-108 (in Polish, English summary).

Grześ M., 1974, Badania nad termiką i zlodzeniem Jeziora Gopło (Investigations of the thermic regime and of ice formation at Lake Gopło), Dok. Geogr. IG PAN 3: 1-57 (in Polish, English summary).

Hodgkins G.A., James I.C., Huntingtin T.G., 2002, Historical changes in lake ice-out dates as indicators of climate change in New England, Int. J. Climat. 22: 1819-1827.

Hurrell J.W., 1995, Decadal trends in the North Atlantic Oscillation: Regional temperatures and precipitation, Science 269: 676-679.

Jańczak J., 2002, Morphogenetic types of Polish Lowland postglacial lakes and their evolution, Limn. Rev. 2: 181189.

Kärkäs E., 2000, The ice season of Lake Pääärvi in Southern Finland, Geophysica 36 (1-2): 85-94.

Kondracki J., 2011, Geografia regionalna Polski (Regional Geography of Poland), Wyd. PWN, Warszawa, 441 pp (in Polish).

Korhonen J., 2006, Long-term changes in lake ice cover in Finland, Nord. Hydrol. 37(4-5): 347-363.

Lange W. (ed.), 1993, Metody badań fizycznolimnologicznych (Methods of physicolimnological studies), Wydaw. UG, Gdańsk, 175 pp (in Polish).

Livingstone D.M., 1999, Ice break-up on southern Lake Baikal and its relationship to local and regional air temperatures in Siberia and to the North Atlantic Oscillation, Limnol. Oceanogr. 44(6): 1486-1497.

Marszelewski W., Skowron R., 2006, Ice cover as an indicator of winter air temperature changes: case study of the Polish Lowland lakes, Hydrol. Sci. J. 51(2): 336-349.

Marszelewski W., Skowron R., 2009, Extreme ice phenomena on the lakes of Northern Poland, Limnol. Rev. 9(2-3): 81-89.

Maślanka W., 2007, Jezioro Raduńskie Górne (Raduńskie Górne Lake), [in:] Borowiak D. [ed.], Jeziora Kaszubskiego Parku Krajobrazowego (Lakes of the Kashubian Landscape Park), Ser. Bad. Limnol. 5, Wydaw. KLUG, Gdańsk: 247-254 (in Polish, English summary).

Maślanka W., Barańczuk J., 2007, Termika i dynamika wód (Thermics and water dynamics), [in:] Borowiak D. [ed.], Jeziora Kaszubskiego Parku Krajobrazowego (Lakes of the Kashubian Landscape Park), Ser. Bad. Limnol. 5, Wydaw. KLUG, Gdańsk: 67-86 (in Polish, English summary).

Naumenko M.A., Guzivaty V.V., Karetnikov S.G., 2008, Surface temperature climatic trends in Lake Ladoga: do they exist during ice-free period?, Limol. Rev. 8(3): 103-108.

Pasławski Z., 1975, Typologia hydrologiczna jezior Pojezierza Wielkopolskiego (Hydrological typology of lakes 
of the Wielkopolskie Lake District), Prz. Geofiz. 20(4): 271-280 (in Polish, English summary).

Pasławski Z., 1982, Zlodzenie jezior w Polsce (Ice conditions of the lakes in Poland), Prz. Geofiz. 27(1-2): 79-92 (in Polish, English summary).

Skowron R., 2003, Ice sheet in the lakes of the Polish Lowland. Distribution, differences and trends, Limnol. Rev. 3: 205-212.

Skowron R., 2011, Zróżnicowanie i zmienność wybranych elementów reżimu termicznego wody w jeziorach na Niżu Polskim (Diversity and variability of selected elements of the thermal regime of water in lakes in the Polish Lowlands), Wydaw. Nauk. UMK, Toruń, 345 pp (in Polish, English summary).

Sobolewski W., Borowiak D., Borowiak M., Skowron R., 2014, Baza danych jezior Polski i jej wykorzystanie w badaniach limnologicznych (Database of Polish lakes and its use in limnological studies), Wydaw. UMCS, Lublin, 198 pp (in Polish).

Świrski Z., 1947, Wskazówki dla obserwatora stacji wodowskazowej (Recomendation for the observer of the water gauging post), Ser. A: Instrukcje i podręczniki Nr 8, PIHM, Warszawa, $31 \mathrm{pp}$ (in Polish).

Trusewicz Z., Markowski M., Barańczuk J., 2009, The influence of the North Atlantic Oscillation on variability of surface temperature of Lake Raduńskie Górne, Limnol. Rev. 9(2-3): 55-62.

Williams G., Layman K.L., Stefan H.G., 2004, Dependence of lake ice covers on climatic, geographic and bathymetric variables, Cold Regions Sci. Technol. 40: 145-164. 